\title{
Anna Mamulska
}

Państwowa Wyższa Szkoła Zawodowa

im. J. A. Komeńskiego w Lesznie

\section{Wychowanie moralne w dziewiętnastowiecznych polskich czasopismach zaboru pruskiego dla dzieci}

Do zadań wychowania od zawsze należało kształcenie moralne jako składnik docelowej formacji człowieka dorosłego i jako takie - należało do najważniejszych.

W dziewiętnastym stuleciu wyodrębnia się pedagogika jako dyscyplina naukowa, która, według J. F. Herbarta, wyznaczała i uzasadniała cel wychowania oraz pokazywała drogę do jego osiagnięcia, jak i środki temu służące. Według tych założeń celem wychowania było wykształcenie moralnie silnego charakteru, a środkami temu służącymi były: kierowanie wychowankami, pielęgnowanie ich rozwoju, wdrażanie do porządku, karność i nauczanie łączone z procesem wychowania ${ }^{1}$. Herbartyzm $w$ myśleniu pedagogicznym zdominował dziewiętnastowieczną Europę, w tym obszar wpływów niemieckich, a więc i zabór pruski.

Szczególną wagę dla budowania świadomości elit zaboru pruskiego, ale i innych ziem polskich, miała tworząca podwaliny dla działania na polu wychowawczym, powstała $\mathrm{w}$ Wielkopolsce $\mathrm{w}$ latach czterdziestych i pięćdziesiątych XIX w. myśl społeczna filozofów narodowych: Karola Libelta, Augusta Cieszkowskiego i Bronisława Trentowskiego. Przekaźnikiem idei filozofów stały się oficyny publikujące ich dzieła, księgarnie i prasa².

Społeczeństwo polskie zamieszkujące obszar zaboru pruskiego było zróżnicowane pod względem statusu społecznego, zamożności, poziomu wykształce$n^{3}{ }^{3}$. Kształtowanie jego świadomości narodowej stanowiło złożony i długotrwały proces. Jednym z czynników warunkujących ten proces było to, że Wielko-

\footnotetext{
${ }^{1}$ J. F. Herbart, Pedagogika ogólna wywiedziona z celu wychowania, Warszawa 2007.

${ }^{2}$ Np. „Szkoła Polska” (1849-1853), „Oświata” (1865-1867), „Przyjaciel Ludu” (1834-1849), „Pismo dla Nauczycieli Ludu i Ludu Polskiego” (1845-1846), „Staszyc” (1889) i in.

${ }^{3}$ J. Kozłowski, Wielkopolska pod zaborem pruskim w latach 1815-1918, Poznań 2006, s. $18-53$.
} 
polska stanowiła obszar pogranicza, miejsce osiedlania się przybyszy z zachodnich i południowych obszarów Europy (Niemcy, Niderlandy, Szkocja, Czechy), zatem automatycznie dokonywało się utożsamianie narodowości polskiej z przynależnością do Kościoła katolickiego.

Ważne dla rozwoju teorii, ale przede wszystkim dla stymulowania praktyki wychowawczej było powstanie w Poznaniu (6 grudnia 1848) pierwszej na ziemiach polskich organizacji pedagogów - Towarzystwa Pedagogicznego i jego organu prasowego „Szkoła Polska”, związanego z postacią Ewarysta Estkowskiego, który o celach wychowania mówił: „ciału nadać zdrowie, siłę, zręczność, i szlachetną postawę, a siłom duszy doskonałość, do jakich są zdolne"

Rozwój prasy pod zaborem pruskim nastąił po Kongresie Wiedeńskim, wtedy bowiem ,,...] klimat społeczno-polityczny w Wielkopolsce sprzyjał różnym działaniom na polu kultury, w tym również rozwojowi czasopiśmiennic-

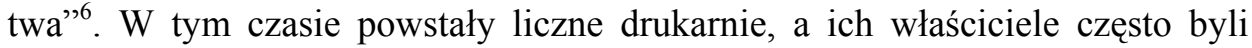
równocześnie wydawcami i księgarzami ${ }^{7}$.

Równocześnie trzeba pamiętać o ograniczeniach, jakim podlegali wydawcy. Wielkopolska weszła w skład monarchii pruskiej w 1793 r. W Prusach wydawnictwa podlegały cenzurze ${ }^{8}$. Na terenie Wielkiego Księstwa Poznańskiego do 1831 nie ukazywało się żadne pismo dla dzieci. Dopiero w roku 1832 pojawiły się „Rozrywki dla Dzieci. Oddział powtórny” Klementyny z Tańskich Hoffmanowej i nieco późniejszy, ale i dłużej ukazujący się „Magazyn Powieści dla Dzieci" (1836-1838). Poznańska drukarnia braci Scherk, wydawca magazynu, którego żywot trwał dwa lata, dostarczała dzieciom lektury znanych i chętnie wydawanych autorów. Po ośmioletniej przerwie lukę wypełnia leszczyński rocznik „Gwiazdka” (1846-1848). Był on przez trzy lata dostarczany dzieciom jako prezent bożonarodzeniowy. W tym okresie pojawia się na rynku wydawniczym czasopismo E. Estkowskiego „Szkoła Polska” (1849-1853) i towarzyszące mu dodatki: „Szkółka dla Dzieci” i „Szkółka dla Młodzieży”. Pisma te, jak pisał Piotr Chmielowski, swym poziomem górowały nad innymi adresowanymi do dzieci ukazującymi się na ziemiach polskich: ,[...] pod względem wartości wewnętrznej, przez czas wprawdzie krótki, góruje Poznań"’. Zamyka ten okres

${ }^{4}$ S. Truchim, Historia szkolnictwa i oświaty w Wielkim Księstwie Poznańskim 1815-1915, Wrocław-Lódź, 1967, s. 239-250.

${ }^{5}$ E. Estkowski, Jakie być powinno wychowanie młodzieży, zwłaszcza męskiej, „Szkoła Polska" 1853 , s. 62.

${ }^{6}$ R. Kowalczyk, Zarys dziejów prasy lokalnej w Wielkopolsce, Poznań 2006, s. 10.

${ }^{7}$ A. Jazdon, Polski ruch wydawniczy w Wielkim Księstwie Poznańskim w latach 1831-1862, Warszawa 1990, s. 10-44.

${ }^{8}$ G. Kucharczyk, Cenzura pruska w Wielkopolsce w czasach zaborów, Poznań 2001, s. 23-24.

${ }^{9}$ P. Chmielowski, Czasopisma polskie dla młodego wieku, [w:] Encyklopedia wychowawcza, t. 3, red. J. T. Lubomirski, E. Stawiski, S. Przystański, J. K. Plebański, Warszawa 1885, s. 111. 


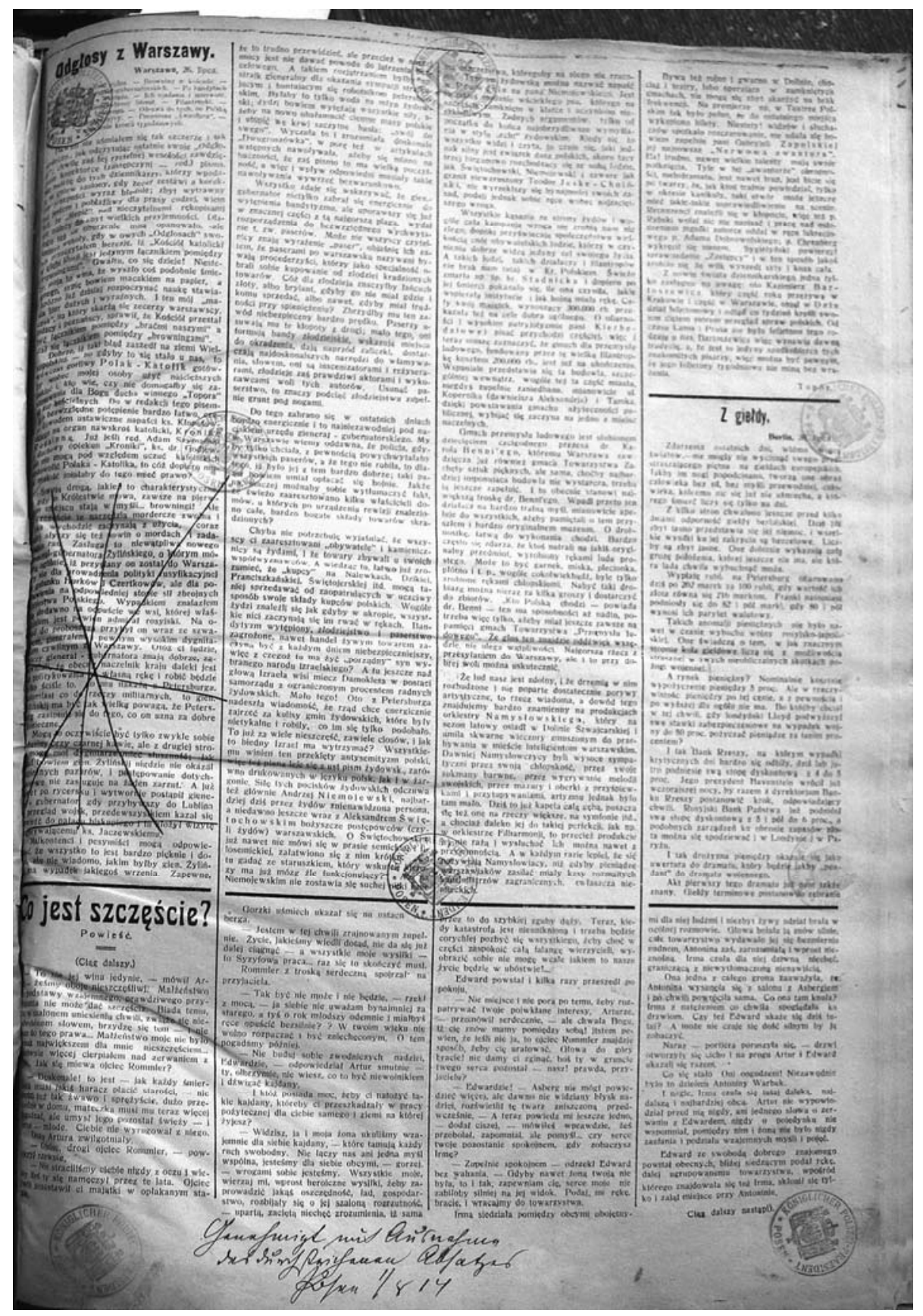

Ryc. 1. Cenzura prasy w zaborze pruskim po 1848 r. miała charakter represyjny, chociaż w różnych okresach zróżnicowane było jej nasilenie. Ingerencje cenzora w wydrukowanym już materiale prasowym „Orędownika” z 1914 r. na miesiąc przed zamachem w Sarajewie (fotografia egzemplarza ze zbiorów Poznańskiego Towarzystwa Przyjaciół Nauk) 
Nr. 18. Poxnań, dnin I-go lcwletula 1909.

Rok VTr.

\section{Przyjaciel Driatwy.}

Bezplatuy dodatek do „Przyjaciela Ludu,“

proznaczony ku nauce I rozrywee naszej kor-hanej dzatwy polskloj.

\section{Prosba o modlitwę.}

W tym tygedniu zmóweie, Kochane Dxia. thei codziennio 1 Ojeze nasz, I Zdrowas $\mathrm{Ma}$. rya i 5 razy: Ktorya za nas eierpial rany. Jezu Chryate ukrzyzowany, badz pochwalo. ny I uwielbiony i zmiluj się nad nami!

\section{stor \\ Modlitwa dziecięcia.}

Boke, w Twojo Imię Aw.ęto Zaczynamy prace dzienne,

Bo w ten sposob rozpoezote.

Plony dadzi nam zbawienno.

Czy zabawa, ezy nauka,

Niech zaczyna się od Ciebie:

A kto Twogo wapareia azuka,

W kazdej dozna go potrzebie.

Gdy się modla dobre dziatki,

'Ty ieh prosbom ezynisz zadose,

I dla ojea i dla matk

Zsylae raczysz zdrowie, radosc.

Poblogoslaw i nam, Panio,

Dozwol w enoeie sie ustalié,

Byámy mogli w kaz̀dym stanio

Bliznich wapierac, Ciebie chwalic.

\section{कबल \\ Kotek Mruczek.}

Był sobie kotek jeden maly, Mruezkiem go dzieoi nazywaly, uszki mu slicznie staly w góre, zas wloski mial on szare, bure, Oczeta Mruczok minl zielone I wasy dlugie, nastroszone, jak jaka szezotka. Lubila lasdzo tego kotka Zosia, co ma niebieskic. oezki, rózowa buzię, jasne loozki. A platal Mruezok psoty - raz poprzez rowy, poprzez ploty mknat na pole w awiat dnfekr, gedzie ponad atromym brzegiom rzoki cliat nie okienka malo fivieç. IV tem od zagrody z za optotka, znienacka wypadl wprost na cotkn pies bartzo srogi.

Mruezek iv nogi. \%o strachu kot zęba. mi dzwoni, pies za nim szezeka, pędzi, goni. An! stol w polı osiczyna - na niq się bury Mruezel wspina, Iuli wię w górzo do galezi, a Latka trzyma go w uwiezi i szezeka; hau, liuu, panio hury, cleciales pewnie dusic kury.

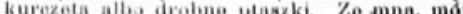

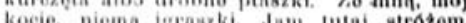
kowe, nientina
obroneq.

Kotok po sobie kladzio uszy, ealy się jez̀y, ogon puszy, na latky mruczy, parskn, pryha. l.eez tiatka groznio w dole ezyha. Jak zeloy latki blvazezil groznie, a tu wi-

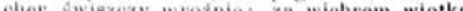

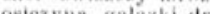

W tom droga $x$ miasta woz siy toczy. na shwile pios oderwal oezy od drzowa! Szust! juz Aruezek skoozy przez pola, ploty, przez zugrody \&wisnal, z Burkiem mknie w zawody, wo wrota domu swego wpada

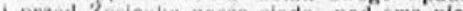
dola meuezy, bindas yosia, nad kwy niedola mruezy, biada. Zosia mu odpowiada:
Dobra to bardzo jest nauezka dla wlocozki. Dobra lo bardzo jest nauezka dla wloczyki
ja pana Mruezka; to zlo ei bylo biale mle. ezko, smietanka x chlebem lub buteozka, wloczye sie musisz kotku bury i z ehat wy kradać eudze kury. Nie kocham swego jut koteczkn, lepsza i milsza mi laleczka.

A kotek biodny bardzo prosi o przeba. ezenie panny \%osi.

\section{stise}

Chata wuja Tomasza.

Powieść z zyoia murzynów w stanaoh Poln. Ameryki.

$$
\begin{aligned}
& \text { (W opracowanlu dla drieoi). } \\
& \text { (Ciag dalszy). }
\end{aligned}
$$

- Widzisz pan, nam przyjaciela, ktory lupuje ladinych chlojésw, liodujo ich, a pó. tiilej sprzodiajo. Jest to przedmiot zbytico. wy Һиршј" go hogacxe i dobrze placa Ladny ehlopies, stojucy u drzwi, stanow ozclobe pañsiogo domu. Handel taki joa

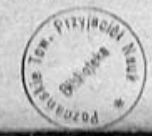

Ryc. 2. Uporządkowanie przekazywanych treści według hierarchii ważności - rozpoczęcie zwróceniem się do Boga. „Przyjaciel Dziatwy”. Dodatek do „Przyjaciela Ludu” z 1909 r., nr 13 (fotografia egzemplarza ze zbiorów Poznańskiego Towarzystwa Przyjaciół Nauk) 
leszczyńskie „Światełko” (1862), którego los przesądziło ograniczenie względnego liberalizmu zaborcy w stosunku do Polaków i wprowadzone zaostrzenia administracyjne wobec prasy ${ }^{10}$. Lata kolejne przynoszą w zakresie piśmiennictwa dla dzieci cenne inicjatywy Józefa Chociszewskiego. Powstał „Przyjaciel Dzieci” (1866) ukazujący się w Pelplinie i Chełmnie oraz „Przyjaciel Dzieci i Młodzieży" (1869-1873) początkowo wydawany w Chełmnie, a pod koniec tego okresu przeniesiony do Poznania. Ważnym dla kultury wydarzeniem było powołanie poznańskiego „Promyka”(1872), redagowanego przez Władysława Bełzę. Po roku działalności w Poznaniu, w związku ze wzmożoną germanizacją i nakazem opuszczenia przez Bełzę zaboru pruskiego, redakcję przeniesiono do Lwowa $^{11}$.

Działalność prasowa na rzecz dzieci polskich dla wielu wydawców pism wiązała się z szykanami w życiu zawodowym, a nawet $\mathrm{z}$ okresowym pozbawieniem wolności. Świadczą o tym losy Józefa Chociszewskiego, długiej, bo jedenaście osób liczącej listy redaktorów „Przyjaciela Dziatwy”12, ks. Józefa Kłosa, ks. Symforiana Tomickiego, ks. Antoniego Ludwiczaka. Trudno byłoby wskazać wydawcę czy redaktora pisma w języku polskim dla dzieci w zaborze pruskim, którego nie spotkały trudności, ograniczenia, zakaz wykonywania zawodu, kary pieniężne czy więzienie.

Warunki powodowały upadek powoływanych tytułów, ale na ich miejsce wkrótce wkraczały nowe. W monografiach dotyczących literatury dla dzieci w XIX stuleciu spotkać można słuszne stwierdzenia o krótkotrwałości czasopism dla dzieci w zaborze pruskim. Było to (prawdopodobna) przyczyną braku zainteresowania badaczy tym piśmiennictwem. Jednak analiza warunków, w jakich działali wielkopolscy wydawcy i konsekwencja w powoływaniu nowych tytułów skłania do refleksji i pochylenia się nad zbiorowym dorobkiem pisarzy, drukarzy, wydawców prasy dla dzieci.

Prezentacja historii prasy dla dzieci na ziemiach polskich w XIX w. zwykle ogranicza się do przedstawienia kilku tytułów najważniejszych w opinii piszących. Najpełniejszy obraz dziejów polskiej prasy dla dzieci ukazuje Stanisław Grabowski w książce Na przyszły pożytek. Jednak uwagę autora pochłaniają głównie czasopisma zaboru rosyjskiego, zaś o pozostałych znaleźć można jedynie wzmianki.

${ }^{10}$ W. Frąckowiak, Polskie czasopiśmiennictwo dla dzieci i młodzieży na Pomorzu w latach 1865-1920 oraz jego aspekty oświatowe i patriotyczne, „Kwartalnik Historii Prasy Polskiej” 1978, t. 17 , nr 2 , s. 6 .

${ }^{11}$ S. Grabowski, Na przyszły pożytek, Pułtusk 2001, s. 87.

${ }^{12}$ Byli to: M. Majerski, B. Sobiechowski, S. Rożanowicz, M. Piechowski, J. Ziółkowski, J. Szczepański, S. Paszliński, L. Kowalski, B. Szczuka, F. Bielicki, M. Noskowicz; W. Frąckowiak, Pedagogiczne tendencje pomorskiej i kujawskiej prasy polskiej dla dzieci i młodzieży w latach 1891-1920, Bydgoszcz 1981, s. 165-180. 
Bogumiła Kosmanowa zauważa, iż „Na XIX wiek przypadł ogromny rozwój prasy, która, początkowo elitarna, z czasem przybrała charakter masowy"13. W Wielkopolsce $\mathrm{w}$ tym czasie ukazywały sie gazety codzienne ${ }^{14}$, pisma pedagogiczne $^{15}$, magazyny rodzinne ${ }^{16}$, satyryczne ${ }^{17}$, religijne ${ }^{18}$.

Listę czasopism polskich dla dzieci w zaborze pruskim otwiera w $1832 \mathrm{r}$. Klementyna Hoffmanowa, wznawiając „Rozrywki dla Dzieci”, których tom 1 wyszedł w Poznaniu nakładem Nowej Ksiegarni J. A. Munka, Druk Pompejusza i Sp. (pełny tytul).

Kolejno ukazujące się tytuły to pisma dla dzieci i dodatki do pism dla dorosłych:

- „Rozrywki dla Dzieci. Oddział powtórny” (1832),

- „Magazyn Powieści dla Dzieci” (1836-1837),

- „Gwiazdka dla Młodzi Katolickiej” (1846-1848), rocznik,

- „Szkółka dla Dzieci” (1849-1853), dodatek do „Szkoły Polskiej”,

- „Szkółka dla Młodzieży” (1854-1855), dodatek do „Szkoły Polskiej”,

- „Światełko” (1862), kwartalnik,

- „Przyjaciel Dzieci” (1866-1869), sześciotygodnik,

- „Przyjaciel Dzieci i Młodzieży” (1869-1873), dodatek do „Katolika”, tygodnik,

- „Promyk” (1871), później ukazywał się we Lwowie jako pismo dekadowe,

- „Dzwon Wielkopolski” (1878), miesięcznik,

- „Nasza Gazetka”, dodatek do „Nadgoplanina” (1887-1891), miesięcznik,

- „Pomoc” (1888), tygodnik,

- „Szkółka Domowa” (1894-1900), dodatek do „Gońca Wielkopolskiego”, tygodnik,

- „Opiekun Dziatek” (1897-1939), dodatek do „Przewodnika Katolickiego” tygodnik,

- „Przyjaciel Dziatwy” (1908-1911), dodatek do „Przyjaciela Ludu”, tygodnik,

- „Przyjaciel Dzieci” (1912-1916), dodatek do „Orędownika”, dwutygodnik.

Poszukując informacji o wychowaniu moralnym dzieci polskich w zaborze pruskim, trzeba pamiętać, iż zakłada ono przyjętą przez wychowującego koncepcję moralności, która określa ideał moralny człowieka, uzasadnia go, wskazuje model wychowawczy. Ten zaś wyznacza cel wychowania. Może nim być przystosowanie człowieka do życia w społeczeństwie, przyjęcie określonych poglądów i sposobów zachowań zgodnych z oczekiwaniami społeczności, w której żyje.

\footnotetext{
${ }^{13}$ B. Kosmanowa, Biblioteki polskie w Wielkim Księstwie Poznańskim, Poznań 1982, s. 31.

${ }^{14} \mathrm{~Np}$. „Goniec Wielkopolski”, „Orędownik”, „Przyjaciel Ludu”.

${ }^{15} \mathrm{~Np}$. „Kościół i Szkoła”, „Szkoła Polska”, „Pedagog”.

${ }^{16} \mathrm{~Np}$. „Dziennik Domowy poświęcony życiu domowemu, familijnemu i towarzyskiemu”.

${ }^{17} \mathrm{~Np}$. „Mrówka Poznańska. Pismo ku użytecznej zabawie rozumu i serca”.

${ }^{18}$ Np. „Prawdą a Bogiem. Pismo tygodniowe dla ludu katolickiego”, „Katolik”, „Przewodnik Katolicki”.
} 
Wychowanie moralne doprowadzić ma do umiejętności dokonywania ocen i podejmowania decyzji zgodnych z przyjętą w ideale wychowawczym hierarchią wartości. Wartości moga przybierać postać dóbr, idei, myśli, postaw, przeżyć psychicznych. Dzielić je można na podstawowe, właściwe dla danego systemu społecznego, wynikające z nich - wtórne, oraz indywidualne, stanowiące twór poszczególnych ludzi. Wartości historycznie podlegają zmiennej ocenie. „Tradycyjnie, pożądane systemy wartości tworzyły określone ideały wychowania, przyjmowane za punkt wyjścia przy określaniu celów działań wychowawczych i samowychowawczych. Dziś kojarzone z narzucanym wzorem, schematem, przedmiotowym traktowaniem wychowanka, budzą sprzeciw lub przynajmniej głęboki sceptycyzm" 19 .

Uzasadnieniem przyjęcia i uznania ideału jest autorytet wychowującego, który reprezentują: rodzice, społeczność, tradycja, religia, władza, przywództwo. Zastosowanie takiego modelu wychowawczego szczególnie uzasadnione jest $\mathrm{w}$ odniesieniu do dzieci ${ }^{20}$. Jednocześnie trzeba zauważyć, że taki model charakteryzuje się dużym autorytaryzmem i wpływa na podejmowanie decyzji moralnych. Dlatego w modelu wychowania moralnego pojawić się musi miejsce na autonomię, miejsce na własną ocenę czynu, na refleksję. Zadanie to ułatwiać miała literatura, w tym prasa dla dzieci, konkretyzując przyjęty model. Model wychowawczy przybiera określoną formę, która zwykle zawiera co najmniej dwie warstwy: normatywną i motywacyjną. Warstwa normatywna modelu wychowawczego ma za zadanie wpływać na działanie wychowanka. Wychowujący działa udzielając wskazówek i zaleceń, wysuwając postulaty, prezentując przykłady postępowania. W przypadku prasy dla dzieci działanie to przyjmowało formę porady, zalecenia, odpowiedzi na słane do redakcji pisma listy. Motywacyjna warstwa modelu wychowawczego charakteryzuje się pośrednim oddziaływaniem na wychowanka, zmierzającym do zmiany jego stosunku do ludzi, sposobu widzenia świata, myślenia, wartościowania. W tej roli znakomicie mogła się znaleźć prasa adresowana do dzieci, gdyż zmiana taka jest możliwa dzięki dotarciu do czytelnika, działaniu na jego system wiedzy, wywołaniu pozytywnego odbioru, zaakceptowaniu przez czytelnika przekazanej informacji, wyzwoleniu pozytywnych emocji wobec prezentowanego zjawiska, zachowania, osoby, wreszcie utrwaleniu nabytej wiedzy.

Badanie zawartości czasopism dla dzieci ukazujących się w zaborze pruskim w XIX w. jednoznacznie wskazuje na istotny ilościowo udział treści umoralniających. Różnie jednak kształtuje się frekwencja ${ }^{21}$ tej tematyki. Otwie-

${ }^{19}$ K. Olbrycht, Wychowanie a wartości, [w:] Pedagogika ogólna. Problemy aksjologiczne, red. T. Kukołowicz, M. Nowak, Lublin 1997, s. 48.

${ }^{20}$ J. Piaget, Psychologia dziecka, Wrocław 1996; M. Debesse, Etapy wychowania, Warszawa 1996, s. 63-65 i 82-86.

${ }^{21}$ Frekwencję tematyki ustalano jako średnią arytmetyczną wg wzoru: $\mathrm{f}=1: \mathrm{n}, \mathrm{w}$ którym: f - frekwencja, 1 - liczba tekstów o określonej tematyce w analizowanej liczbie numerów czasopisma, $\mathrm{n}$ - liczba analizowanych numerów czasopisma. 
rające listę „Rozrywki dla Dzieci. Oddział powtórny” przeniknięte są tematyką moralną. Na sześć tekstów zaprezentowanych w periodyku, jedynie słownik nie jest nośnikiem tych treści. W „Magazynie Powieści dla Dzieci” średnio dziewięć tekstów w numerze przekazuje te treści, sześć periodyków („Dzwon”, „Pomoc”, „Nasza Gazetka”, „Przyjaciel Dzieci i Młodzieży”, sześciotygodnik „Przyjaciel Dzieci” i dwutygodnik „Przyjaciel Dzieci”) zamieszczają po dwa teksty na numer. Pozostałe czasopisma zamieszczają $\mathrm{w}$ numerze średnio jeden tekst o tematyce moralnej. Wyjątkiem jest „Szkółka Domowa”, która tego typu treści (w jednym tekście) zamieszcza średnio w co trzecim numerze.

Przeprowadzenie analizy treści materiałów publikowanych $\mathrm{w}$ prasie dla dzieci zaboru pruskiego dało możliwość sformułowania wniosków dotyczących wskazywania młodemu odbiorcy określonych wartości. Przede wszystkim dostrzec można uporządkowanie tych wartości. Tworzą one w badanych czasopismach jasną hierarchię, ze względu na ich częstotliwość występowania w określonych tytułach.

\section{Wartości patriotyczne.}

Na pierwszym miejscu stawiany jest patriotyzm.

Córko i synu tej ziemi

Ojczyzna pierwsza po Bogu

Służ jej od młodości progu,

Kochaj siłami całemi ${ }^{22}$.

Spotkać możemy tę wartość w przykładach konkretnych czynów bohaterów historycznych, których postępowanie stanowi wzorzec zachowania. Pisma tworzą cykle historyczne prezentując bohaterów narodowych ${ }^{23}$, których życie stanowi wzór osobowy do naśladowania. Podobne zadanie spełniają przykłady literackie, fikcyjne ${ }^{24}$, których fabuła wprowadza czytające dziecko w realia znane $\mathrm{z}$ własnej obserwacji przez co bliższe i łatwiejsze do zaakceptowania. Miłość do ojczyzny znajduje odzwierciedlenie w pogadankach, poezji, a nawet w bajkach.

Kochaj Polskę i wszystko, co się w niej znajduje,

A będziesz szczęśliwym, radość serce uczuje.

U nas wszystko ładniejsze - $\mathrm{i}$ to wszystko nasze

Czy to dziewczę, czy kwiatek, czy to chłopiec, czy ptaszę ${ }^{25}$. z. 1 , s. 1 .

${ }^{22}$ M. Sokolnicka, Co to Ojczyzna, „Pomoc. Pismo czasowe dla młodzieży i domu” 1888,

${ }^{23}$ nn, Floryan Szary, „Nasza Gazetka” Dodatek do „Nadgoplanina” 1888, nr 1, s. 4.

${ }^{24} \mathrm{nn}$, Mały kantonista, „Przyjaciel Dzieci i Młodzieży” 1872, nr 20, s. 166.

${ }^{25}$ Aldona, Nasza Ziemia, „Pomoc. Pismo czasowe dla młodzieży i domu” 1888, z. 3, s. 1. 


\section{POWROCT DO OJCZYZNY. \\ $+2 x=50 \times 2$}

Witsj ojexyete xie. coin's suk cudois ris prowis

Twe keny wyxkete neW exechupene. yo dignis.

Tentrowienieszom ryses po etroteych kewieniech,

To yeje w xtorych pleras plysalikwy cispisel.

To xiki etrojue xwethw is tigle kobieresen,

Gadojace tíe * ?, kiew sxtowirks, lec\% $\%$ eserees

Witoj xiewio wexy. ele, is pochylowy

\$ryyku, xyory uris disxy poupistuy zeyony,

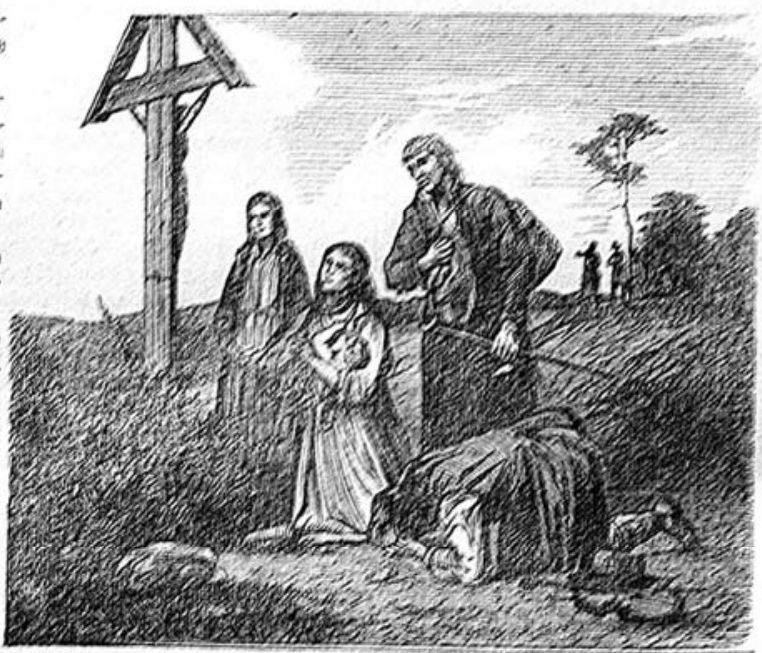

Sie dwoje bleng Ew oteroztester rewione, sak ydybys wexyeb. ke riewig slcies ivilis do koue. opowiedz, sxy of prothe nieszer. spych doled. Opowieds krzyzi etery exy pryy? miesx twe dxised

Diewdrinezoi, my 8 my sisbie 94 biepli o Chryet. Porzucili dow wi? sny, tany weele rzyete,

"Nwylyietsi, sxy oss gussi cxuwa Ator Two Bots,

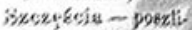
Emy wzukas het w\% za trzy coorze.

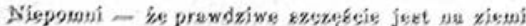

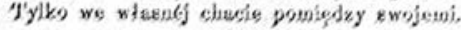

facts! ofo etopy nesze bose, pokrwewione, Dtowie od niexwierneg" trudu vxugjoue,

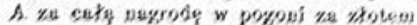

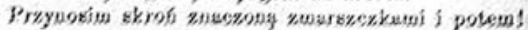

I jedne probeg sxepen uely napiektemi!

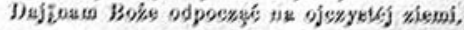

y, Belze.

Ryc. 3. Czasopisma dla dzieci łączyły tematykę patriotyczną z religijną. „Dzwon Wielkopolski” 1878, z. 3, s. 60 (fotografia egzemplarza ze zbiorów Poznańskiego Towarzystwa Przyjaciół Nauk) 


\section{PRZYJACTEX DZIECI i HLODZIEZL.}

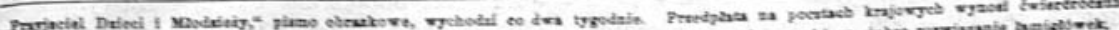

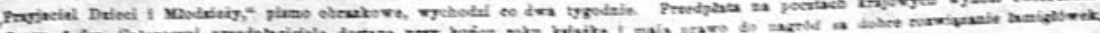

Nr. 1 .

Jan Matejko, najslawniejszy polski malarz.

Na cala Polske, owszem daleko po za Polski granicami slynie wielce Jan Matejko, nietylko jako najshawniejszy mslarz polski, sle takze jako jeden $z$ najsławniejszych malarzyświata. Jego przesliczne odrazy zach wycają i zdu miewajạ. Ztạd shuszna, te nasze pismo, rozpoczynaj a c rok piątyistnieni a poda je swym młodym czytelnikom życiorys i wizerunek tego wielkiego mistrza w malarstwie, kt6ry nietylko siebie, ale $i$ caly naród polski sławą okrył niemals :

Urodził się

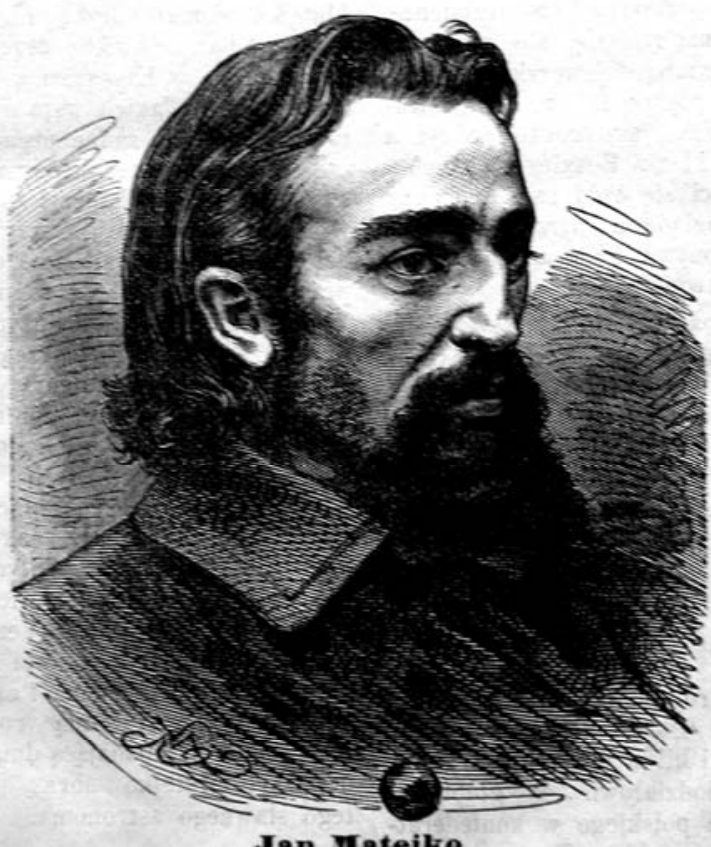

Jan Matejko.

do pracy. Juz w dziecięcych leciech młody Jan czuł pocigg do malarstwa. Z upodobaniem czrtal Spiewy Historyczne Niemcemicza i przerysowywal ryciny $z$ tego dzieła. Spiewy te już niejednego Polaka ns dobra naprowa dziły droge, jak oto np.najsławniejszego polskiego muzyka Moniuszle, w którym przez nucenie tych pięknych pieśni obudzil się potẹżny talent muzykalny.

W czternastym rokużycis zaczął Matejko uczesszeza ć do szkoły malarskiéj w Krakowie. Tu odzn acza wielkş pilnoscią. Pierwszy jego obraz samodzielny wyobraza carów Szujskich, stojących przed ZygmuntemIII. Liczył wtedy Jan Matejko 30 Lipca 1838 r. w Krakowie. | nasz artysts, kiedy ten obraz malowal, szeRodzice starali się usilnie, aby go wychować snaście lat tycia. Niedługo wykonał kilka bogobojnie i zaszczepic w nim zamiłowanie innych obrazow, a mianowicie: Wjazd Hen-

Ryc. 4. Dzieci poznają wzorce osobowe - „,.. wizerunek wielkiego mistrza w malarstwie, który nie tylko siebie, ale i cały naród polski sławą okrył niemałą. I dalej: „Matejko może posłużyć za wzór dla dzieci, że tylko usilną pracą i nauką można rozwinąć wrodzony talent”. „Przyjaciel

Dzieci i Młodzieży” 1873, nr 1, s. 1-2 (fotografia egzemplarza ze zbiorów Poznańskiego Towarzystwa Przyjaciół Nauk) 


\section{Religijność.}

Równie ważna, wiązana z patriotyzmem, jest religijność. Sprawy wiary, postawy wynikające $\mathrm{z}$ faktu bycia dzieckiem Bożym, stale obecne są na łamach pisemek.

Pogadanki nakłaniają czytelników do określonych zachowań, odpowiedzi na listy rozwiewają wątpliwości, hasła i sentencje wskazują drogę do celu. Pogłębieniu pobożności służą modlitwy i intencje modlitewne skłaniające dzieci do modlitw np. za rekrutów, więźniów, o dobrą spowiedź itp. Nakłania się dzieci do określonych zachowań:

musisz domek serca twego tak urządzić, żeby to Boskie Dziecię chętnie w nim przebywać mogło. Ty musisz z niego wyrugować wszystko to, co ze złej woli pochodzi, to się Jemu nie podoba. A ty już przecież wiesz, co się Jemu nie podoba, a więc dobrowolne kłamstwo, nieposłuszeństwo, nieprzystojne zachowanie, a szczególnie niewstyd ${ }^{26}$.

W wielu utworach przeznaczonych dla dzieci cechą istotną jest ufność w boską opiekę. W „Magazynie Powieści dla Dzieci i Młodzieży” w każdym utworze spotykamy przykłady na potrzebę zawierzenia opatrzności i pozytywne tego skutki ${ }^{27}$. Ufność w opiekę boską wsparta powinna być działaniem wyrażającym się w zaradności życiowej.

\section{Pracowitość.}

Kto chce i umie pracować jak trzeba

Ten w każdym kraju dorobi się chleba ${ }^{28}$.

Szacunek dla pracy ${ }^{29}$ i pracowitość to kwestie stale podnoszone. Pisma dostarczają dzieciom wzorców, ale i piętnują postawy lenistwa, nierzetelności czy braku poczucia obowiązku. Ważne, aby dzieci traktowały swoje drobne obowiązki z powagą i starannością, dlatego często $\mathrm{w}$ czasopismach przypomina się o obowiązku nauki (własnej, ale i uczenia osób niższego stanu):

Pracuj pilnie w zawodzie twoim. Zawód ucznia jest pięknym, szlachetnym powołaniem [...]. Czas nauki jest chwilą siewu, użyj tego drogiego czasu nim upłynie - gdyż inaczej nie można spodziewać się korzystnego żniwa ${ }^{30}$.

${ }^{26}$ nn, Grudzień, „Nasza Gazetka” Dodatek do „Nadgoplanina” 1889, nr 12, s. 45.

${ }^{27} \mathrm{nn}$, Robaczek świętojański, ,Magazyn Powieści dla Dzieci” 1836, z. 1, s. 56-66.

${ }^{28}$ nn, Koszykarczyk, „Nasza Gazetka” Dodatek do „Nadgoplanina” 1890, nr 4, s. 2.

${ }^{29}$ nn, Skrzypce, „Przyjaciel Dzieci” Dodatek do „Orędownika” 1912, nr 2 (anegdota o chęci szybkiego osiagania efektu - z morałem, że bez pracy nie ma kołaczy).

30 nn, Baranek, „Magazyn Powieści dla Dzieci” 1837, z. 1, s. 184. 


\section{Dzielność (męstwo).}

Kolejną pozycję w rankingu zajmuje dzielność. Literackim i historycznym przykładom męstwa dorosłych i bohaterskim czynom dzieci towarzyszą niezwykle ważne aktualia dotyczące postaw dzieci wielkopolskich wobec germanizacji i sposobów przeciwstawiania się jej:

pokochać wszystko, co polskie, wszystko, co nasze, [...] modlić się, [...] uczyć się: Kochajmy nasz język, uczmy się czytania i pisania - czytajmy historyę naszego narodu, o naszych królach i bohaterach. Popierajmy swoich, to jest Polaków, wszędzie i zawsze. Kupujmy wszystko tylko w polskich składach ${ }^{31}$.

Zalecane działania znajdują odzew wśród czytelników i mają odbicie w korespondencji do pism. Młody czytelnik, Konstanty Bitoński, w liście do redakcji pisze:

Co teraz szkoła dać nie może, tego się trzeba tym pilniej w domu uczyć i czytać polskie książki i polskie pisma ${ }^{32}$.

Janinka K. spod Kończyc informuje:

ja i mój starszy brat i siostra strajkowaliśmy, ale to nic nie pomogło. Mój brat został teraz na kwietnia ze szkoły wypuszczony. Właściwie miało się to stać już w jesieni, ale za strajk go ukarali ${ }^{33}$.

\section{Dobroczynność, milosierdzie.}

Te wartości równie często jak męstwo poruszane są w pismach dla dzieci. Autorzy w przypowiastkach, anegdotach i wierszykach starają się skłonić czytelników do właściwej postawy, powołując się na zachowania osób świec$\mathrm{kich}^{34} \mathrm{i}$ duchownych ${ }^{35}$.

\section{Mądrość.}

Jest kolejną wyraźnie wskazywaną wartością:

Nie sukienka, lecz rozum nadaje wartości człowiekowi ${ }^{36}$.

${ }^{31} \mathrm{nn}, \dot{Z} a$ łoba (artykuł o odbieraniu ziemi Polakom), „Przyjaciel Dzieci” 1912, nr 3.

32 „Nasza Gazetka” Dodatek do „Nadgoplanina” 1889, nr 4, s. 15.

33 „Przyjaciel Dziatwy” Dodatek do „Przyjaciela Ludu” 1908, nr 18, s. 69.

${ }^{34}$ nn, Ludzkość, „Magazyn Powieści dla Dzieci” 1837, z. 1, s. 50-51 (o wspieraniu przez hrabiego Berchtolda bezpośrednią pracą i pieniędzmi powodzianina).

${ }^{35} \mathrm{nn}, \dot{Z} y w o t$ i sprawy św. Wincentego a Paulo, „Przyjaciel Dzieci i Młodzieży” 1872, nr 22/23, s. 3 .

${ }^{36}$ Zofia An..., Osiełek przebrany, „Przyjaciel Dzieci i Młodzieży” 1872, nr 1, s. 6. 
Dzieci powinny umieć doceniać mądrość, nie kierować się pozorami, starać się pilnie uczyć, mając na uwadze konieczną w tym działaniu cierpliwość.

Mimo przeciwności i chwilowe niepowodzenie musicie dążyć do wytkniętego raz celu, a zwyciężycie ${ }^{37}$.

\section{Ofiarność.}

Ważna jest zdolność do poświęcenia ${ }^{38}$. W przypowieściach, wierszykach spotykamy dzieci, których działania zasługują na nagrodę.

Moje młode czytelniczki uczuły zapewne wzgardę ku temu złośliwemu wójtowi, który przez chciwość nie przestawał dręczyć uczciwą rodzinę zamiast ją poważać, zasłaniać i pocieszać; zapewne polubiły dobrą Zuzię, bo ona poświęciła swoją przyjemność świętej powinności córki, poznają także z tej powieści, że prędzej czy później cnota otrzyma nagrodę, a występek karę ${ }^{39}$.

\section{Prawda.}

Jedną z naczelnych wartości przywoływanych w pismach dla dzieci jest prawda.

Prawda śliczna, prawda święta!

Każde kłamstwo brudne,

Więc się kłamstwa wystrzegajcie

Jak trucizny, dzieci

Wcześnie prawdę ukochajcie,

Co jak słońce świeci ${ }^{40}$.

Dzieci, które kłamią, same sobie szykują karę, kiedy bowiem potrzebują pomocy, nikt nie traktuje ich słów serio ${ }^{41}$.

\section{Grzeczność.}

Często przywoływana jest grzeczność.

Daj, bym w cnoty, jak i w lata

Wzrastał ciągle, dzień po dniu

Ciesząc w drodze tego świata

Boga, ludzi, tam i tu - AMEN $^{42}$.

${ }^{37}$ P., Wytrwałość, „Pomoc. Pismo czasowe dla młodzieży i domu” 1888, z. 2, s. 10.

${ }^{38}$ Miromir, Kto się w opiekę, „Pomoc. Pismo czasowe dla młodzieży i domu” 1888, z. 1, s. 4 (o sierotce Zosi, która oddała lalkę za chleb dla chorej matki).

${ }^{39} \mathrm{nn}$, Zuzanna, czyli dobra córka, „Magazyn Powieści dla Dzieci” 1837, z. 4, s. 130.

${ }^{40}$ nn, Piosnka o prawdzie, „Nasza Gazetka” Dodatek do „Nadgoplanina” 1889, nr 10, s. 39.

${ }^{41} \mathrm{nn}$, Rozpustny Jaś, „Magazyn Powieści dla Dzieci” 1837, z. 1, s. 57-59.

42 nn, Jezus miłośnik dzieci, „Nasza Gazetka” Dodatek do „Nadgoplanina” 1889, nr 12, s. 46 (wierszyk - prośba o pomoc Bożą w dobrym postępowaniu). 


\section{Uczciwość.}

Cnotą cenioną i propagowaną jest uczciwość. Przypowiastki o służących, które dbają o dobro swych chlebodawców, o biedakach zwracających zbyt hojną jałmużnę, często pojawiają się w pismach dla dzieci ${ }^{43}$.

\section{Zaradność życiowa.}

Powiastki tego czasu pełne są historii dzieci porywanych, zagubionych, zamienionych przez służących. Równie częste są przypadłości losu, utrata majątku i pozycji, samotność, fałszywe oskarżenia wrogów. W takich okolicznościach trzeba zachowywać się godnie, szlachetnie i umieć się znaleźć. Ważna zatem okazuje się zaradność życiowa i tę cechę starają się pisemka wskazywać jako istotną ${ }^{44}$. Bywa, że dzieci same muszą radzić sobie, stają się sierotami (częsty motyw) lub okoliczności losu odrywają je od bliskich. Jak się zachowywać, wie każde z nich.

\section{Stosunek do innych ludzi.}

Stosunek do innych ludzi wynika z przykazań boskich. Naczelna jest miłość do rodziców.

Nie zasługuje na żadną litość to plemię tygrysie, co nosząc słodkie imię dzieci, zaniedbuje świętych obowiązków wdzięczności i uszanowania względem rodziców. Pomsta niebios pójdzie za takiemi, a ich sprawiedliwy gniew Boga dosięże w tem lub przyszedłem życiu ${ }^{45}$.

Przykłady z życia królów, sławnych artystów, ludzi nauki mają utwierdzać czytelników w przekonaniu o konieczności okazywania rodzicom szacunku i miłości ${ }^{46}$. Człowiek dobrze wychowany okazuje szacunek wobec starszych, okazuje również stosunek życzliwy do ludzi niższego stanu ${ }^{47}$. Ważną cechą jest dobroć, cnotliwość i uczynność. Tytuły poświęcanych tej tematyce materiałów mówią same za siebie: Dobry syn, Dobra córka, Poczciwa dziewczyna, Sumienna wieśniaczka, Poczciwość wynagrodzona, Moc cnoty.

${ }^{43}$ nn, Moc cnoty, „Magazyn Powieści dla Dzieci” 1837, z. 1, s. 226-228.

${ }^{44}$ Powieści z „Magazynu Powieści dla Dzieci”, nn, O złej macosze i dobrej pasierbicy, „Nasza Gazetka” Dodatek do „Nadgoplanina” 1890, nr 11-12.

${ }^{45}$ S. Jachowicz, O miłości ku Rodzicom, „Przyjaciel Dzieci i Młodzieży” 1873, nr 6, s. 41-42.

${ }^{46} \mathrm{nn}$, Jak w Polsce synowie czcili rodziców, „Przyjaciel Dzieci” Dodatek do „Orędownika”, 1914, nr 11 (anegdota historyczna o Franciszku Karpińskim); nn, Przykład miłości ku Rodzicom „Nasza Gazetka” Dodatek do „Nadgoplanina” 1889, nr 12, s. 48, (o Bolesławie Krzywoustym, który nosił żałobę po swym ojcu przez pięć lat).

${ }^{47}$ nn, Kładka, „Przyjaciel Dzieci i Młodzieży” 1873, nr 6, s. 43 (historyjka o Krysi, która użyczyła swej huśtawki, aby pomóc żebrakowi przeprawić się przez strumyk). 
Mało uwagi natomiast poświęca się stosunkowi do innych dzieci. Ich relacje najczęściej ograniczają się do rodzeństwa.

Związki rodzeństwa Bóg skleił wespoły, więc się kochajcie jak święte anioły ${ }^{48}$.

Brak jest materiałów ukazujących relacje koleżeńskie czy przyjacielskie. Można odnieść wrażenie, że dzieci raczej obcują z dorosłymi i powinny jak najszybciej takimi się stać.Pisma, jak i książki dla dzieci w tym czasie zamieszczają przerażające historie o złych dzieciach i losie, jaki je spotkał.

\section{Stosunek do przyrody.}

Wśród przymiotów, jakimi powinno cechować się dziecko, pojawia się również stosunek do przyrody, zwierząt i roślin. Pogadanki zakazują krzywdzenia zwierząt:

Kochane dzieci, nie dręczcie zwierząt, bo i one mają czucie i nie na to Pan Bóg je stworzył, abyście je męczyły ${ }^{49}$.

Nieuchronność kary, tragiczny los, kalectwo, a czasem nawet śmierć czekają na złe, krnąbrne, nieposłuszne dzieci. Te konsekwencje czynów dzieci szczególnie mocno podkreśla „Magazyn Powieści dla Dzieci” z opowiastkami księdza Ch. Schmitta ${ }^{50}$, „Przyjaciel Dzieci i Młodzieży” z historyjkami J. Chmielewskiego $^{51}$. W tytułach pojawiają się jednoznaczne określenia: rozpustny, złodziej, szkodnik, nieposłuszny, psotnik, itp. Przestrogi dotyczące właściwego zachowania ostrzegają dzieci, że nawet wtedy, gdy wydaje im się, że są same, to jest ktoś, kto czuwa, widzi je i trzeba dbać o to, by go nie zasmucać. Obecny w sztukach plastycznych, ale i w literaturze, anioł, pilnuje dziecka nawet w kapieli ${ }^{52}$.

Dziewiętnastowieczna prasa dla dzieci w zaborze pruskim stawia sobie wyraźny cel - wychowanie dobrego Polaka. Służą temu ukazywane normy zachowań społecznych, gdzie cnoty osobiste, jak posłuszeństwo, gospodarność, zapobiegliwość, łączyć należy z głębokim umiłowaniem Ojczyzny, roztropnością, ale i gotowością do całkowitego poświęcenia. Sposobem na przekazanie

${ }^{48}$ nn, Dobre siostry, „Nasza Gazetka” Dodatek do „Nadgoplanina” 1890, nr 2, s. 4. nr 6, s. 4 .

49 nn, Co spotkato pastuszka Kube,, „Nasza Gazetka” Dodatek do „Nadgoplanina” 1890,

${ }^{50} \mathrm{nn}$, Skutki łakomstwa, nn, Skutki nieostrożności, „Magazyn Powieści dla Dzieci” 1837, z. 1, s. 51-53, s. 54-55.

${ }^{51} \mathrm{nn}$, Eakoma Zosia, nn, Grzeczny chłopiec, „Przyjaciel Dzieci i Młodzieży” 1871, nr $4 / 5$, s. 34.

${ }_{52}^{5}$ „Nasza Gazetka” Dodatek do „Nadgoplanina” 1889, nr 8, s. 31 (pogadanka w formie uwag Anioła Stróża na temat wstydliwości i skromności przy kąpieli). 
tak ważnych, skomplikowanych, a często, ze względu na cenzurę, niemożliwych do wyrażenia wprost treści, stają się prezentowane wzorce osobowe, które dzięki fabularnemu ujęciu tematu łatwiej przemawiają do wyobraźni dziecka. Historie i historyjki, wierszyki i anegdoty, cytaty wielkich dzieł wykorzystywane przez wydawców, budują jednoznaczny model człowieka pobożnego, wszechstronnie wykształconego, roztropnego, kochającego Boga, Ojczyznę, ludzi nie tylko swojego stanu. Taki miał być nowy Polak, którego zadaniem było odrodzenie Polski. Moralizatorskie w wymowie, różnorodne w formie przekazu, pisemka dla dzieci służyć miały osiagnięciu tego szczytnego celu. 